\title{
MANAGEMENT OF BIO TECHNOLOGIES FOR WINE TOURISM
}

\author{
DAVID LOLUA \\ Associate Professor, \\ Georgian Technical University, Georgia \\ lolua.d@gmail.com
}

https://doi.org/10.35945/gb.2018.06.038

\author{
MANANA ALADASHVILI \\ Associate Professor, \\ European University, Georgia \\ m.aladashvili@gmail.com
}

\section{KEYWORDS: MANAGEMENT, BIO TECHNOLOGIES WINE TOURISM}

Modern international and local tourism market is developing at a fast pace. Due to the global economic importance of tourism ecological and economic factors of the development of separate directions of tourism is given a special significance.

Below we present the aim of our study:

- Study of ecological (Toxicity, Radiation) conditions of the construction materials used in wine tourism in tourist regions of Georgia and their impact on technological characteristics of wine.

- Study of the opportunities for ecologically sustainable, renewable, non-traditional technologies in tourism business and their offer.

In wine tourism one of the main parts of tourism infrastructure are the buildings, in which the technological processing of wine is performed. Wine cellar represents a building for the construction of which modern material and technologies are used. Increasing the development of wine tourism requires fast construction of buildings which is performed using the diversified building materials and new construction technologies. In our markets one can find different kinds of cement, iron, plastics, porcelain and other materials and filling and materials imported from many countries. It should be also noted that, unfortunately, there is no research or study conducted determining the indicators of danger regarding the quality of wine and the threat to health.

Scientists' research proves that the environment, where people live and work, is polluted. At the same time, the radiation background of the atmosphere is increased. In tourism business, particularly in encyclopedic tourism, it is important to take the environment into account, where the wine making and tasting is performed.

Scientists' research has proved the technological radioactivity of building materials. Recently it has been found that some of the natural remedies for the processing of natural raw materials - the ribosomal shale, the waste processing of phosphorus ores, phosphorus, and the ash are characterized by high radio frequency as a result of burning the stainless steel. Some types of coal contain 1 tone of uranium, while oth- er radionuclides are smaller than in the earth's crust. While burning the coal radionuclides are concentrated in slag, including the dust of the gray. The latter is used in cement in some countries.

Toxicity of building materials of natural origin. Attention was drawn to the radioactivity of three-fold materials in the beginning of 70s of the past century and to the toxicity of natural and technological waste construction materials only in recent years.

Asbest-oscritol is the most studied of all the building materials and represents magnesium-water silicate. In nature, asbestos can be found in asbestos fibers and dust particles up to $10 \mathrm{~mm}$ (50\% of mass). According to Asbestos mining, Russia is the first in the world, followed by Canada. Different materials are made of Asbestos like: Shifters; Living, social and industrial buildings - wall panels; Ventilation pipes; Thermal insulation filling solutions; Burning paints. The possibility of using of ashyders asbestos as a mineral powder in Asphalt town is also established.

Toxicity of artificial construction materials. Great caution is required while using new materials. Use of a wide range of materials should be preceded by its comprehensive examination.

St. In Chernov (Russia) in 1988 clay smells were used in bricks: argillite, dispersive coal. Later it was found that the mixture contained Boris fluoride, which was converted into hydrolysis as a hydrolysis that causes hair fall, and the damage of upper respiratory tract and central nervous system.

We have studied the radiation and toxic conditions of the roof, walls and rooms for tourism zones. The radiation background was studied for tourist regions. Radiation background in the closed spaces was studied in different functional rooms. As a result of the survey, the following was established: RF: $107 \pm 0.89 \mathrm{ng} / \mathrm{h}$ in the kitchen and $115 \pm 0.88 \mathrm{ng} / \mathrm{h}$ in the bathrooms; The relatively low was the indicator in places of public gatherings ( $97 \pm 0.88 \mathrm{Ng} / \mathrm{h}$ ). It should be noted that the rate of radiation background in residential houses is close

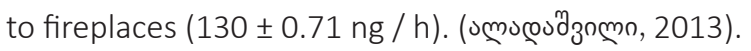

The ecological quality of the construction materials will 
certainly affect the quality of wine making, in the process of milling, because the oxidation-restoration process is in progress in the process which increases the fungicide preparations in the alcoholic fermentation.

We offer you new ecologically clean thermodynamic buildings (thermos) for the new start-up wine producers.

We are presenting alternative, traditional and modern technologies and building materials that can be involved in wine tourism - Eco-homes built from the renewable non-traditional materials (nails, clays). These houses are compared to materials that are used for building tourist infrastructure. We have studied ecologically clean, harmless, cheap, energy efficient, economically efficient buildings - taking into consideration their sustainability, comfort, physical data and energy efficiency. Based on the research, it is established that the pearl ecole is more attractive, harmless and comfortable for

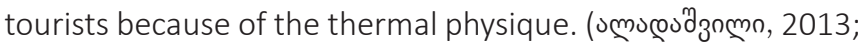
Широков,2010).

Scientists' works have been used in connection with this topic and we had consultations with Professor B. Zhirkov. The Georgian model was developed by us and was adapted to the kvevri wine installed by Kakhetian method.

One of the key components of the ecological assessment of houses is the condition of the isolation of the walls. The pram block of such houses is the best thermal insulator. The thing is that the pressed blocks contain enough amount of air. In addition, the volumetric density of light material determines the low thermal conductivity. Here are the internal and external temperatures, and the most importantly, the humidity. Thermal insulation depends on the thermal conductivity, which in its own turn is determined by the weight (volumetric weight-density), the tanium and the blades in the blade block. The ecosystem constantly maintains the temperature of 14 degrees, so it is possible to leave the wine with permanent temperature and it will not affect its quality. One of the thermal technique characteristics are energy losses that are minimized. (umusoudzomn, 2013).

Eco-houses, which can be implemented in wine tour- ism, are attractive from the point of view of finances as the thermal-physical indicators of the renewable materials used in eco-houses (reduction of energy losses) reduce daily costs by about $11 \mathrm{GEL}$ : providing the heating and hot water supply with solar collectors on average 2,5 GEL, Solar females electrone Receipt of RG by $2 \mathrm{GEL}$ and that will reduce the total cost of the overnight expenses by $15,5 \mathrm{GEL}$, reducing the price of the whole night by $25-30 \%$, which will be reflected on the price of the tour packages that in the long run will result in attraction of tourist flows. We offer you new ecologically clean thermodynamic buildings (thermos) for the new start-up wine producers.

Construction of such ecosystems will help the creation of the network of road camping and road motels in Georgia where wine tasting would be possible. Besides that it would be possible to arrange the caskets by simple portable doors and bungalows according to seasons. All this will improve the servicing of wine tourists.

In addition to wine tourism (ecologially clean and traditionally made wine), it is possible to develop healing tourism.

The medicinal properties of the wine made in the old Kakhetian pitcher are known from ancient times, as it contains a wide range of many natural useful components.

According to the survey during which tourism managers employed in touristic companies of Georgia were interviewed, $100 \%$ of tourists prefer the wine from ecologically healthy environment.

In eco-homes it is possible to merge tourism with enterotherapy (wine treatment) and ampelotherapy (grapes).

In the regions of Georgian, which are rich in wine culture and wine traditions, i.e. Kakheti, it is important to draw the accent on Georgian wine's healing properties in the process of the wine tourism development, which will be produced in the ecologically safe environment and which in its own turn will help attracting more tourists, development of Georgian wine and viticulture and tourism promotion in the region as well as creation of jobs, spa tourism, and finally, popularization of country's tourism image.

\section{REFERENCES:}

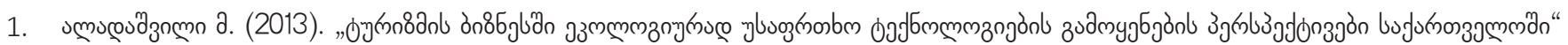

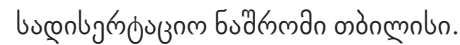

2. ШироковЕ.(2010). Домизсоломенныхблоков. Киев, стр. 214.

3. Сергеев С.,(2008). «Экодом», М.

4. Ruzdi kunc (2010). "Eco house", Switzerland.

5. http://www.domizsolomi.com; 


\section{MANAGEMENT OF BIO TECHNOLOGIES FOR WINE TOURISM}

\section{DAVID LOLUA}

https://doi.org/10.35945/gb.2018.06.038

Associate Professor,

Georgian Technical University, Georgia

lolua.d@gmail.com

\section{MANANA ALADASHVILI}

Associate Professor,

European University, Georgia

m.aladashvili@gmail.com

\section{KEYWORDS: MANAGEMENT, BIO TECHNOLOGIES WINE TOURISM}

\section{SUMMARY}

Offering of new ecologically clean thermodynamic buildings (thermos) for the fresh start-up wine producers is highly relevant in the development of wine quality and wine tourism.

Hereby we are presenting alternatives, traditional and modern technologies and building materials that can be applied in wine tourism - these are the houses made of renewable non-traditional materials (nails, clay). They are compared with materials that are used in the construction of tourist infrastructures today. We have studied ecologically clean, harmless, cheap, energy efficient, economically efficient productstaking into consideration their sustainability, comfort, physical data and energy efficiency.

Eco-homes, which can be used in wine tourism, are also attractive due to the fact that the thermal physiological data of renewable materials used in eco-shops (reduction of energy losses) make daily costs cheaper.
Construction of such ecosystems will help the creation of a road network for camps and mortar network in Georgia, where wine tasting would be possible. Also, by using the panels, it would be possible to arrange a simple type of portable tents and bungalows according to seasons. All this will improve servicing in wine tourism.

In the regions rich in wine traditions and vine culture, such as Kakheti - it is important to focus on the healing properties of Georgian wines in the process of wine tourism development, wines which will be made in the ecologically safe environment that will help attracting more tourists, development of Georgian winemaking and viticulture and stimulation of internal tourism as well as creation of jobs in the region, popularization of healing tourism and touristic image of the country. 